\title{
Development Strategies for Guangxi Sports Tourism Route from the Perspective of "Healthy China"
}

\author{
Wang Dongle ${ }^{1,2}$ Liang Feng $^{1 *}$ \\ Guilin Tourism University, Guilin, China, 541000 ${ }^{1 *}$ \\ School of Marxism Wuhan University of Technology, Wuhan, China, $430072^{2}$ \\ lf@gltu.edu.cn
}

\begin{abstract}
In order to improve the physical fitness of the entire people and enhance physical health, "Healthy China 2030" Plan has been promoted to the major national development strategy. This research uses SWOT model method, effectively combines "Healthy China" outline policy. By analyzing the advantages and disadvantages of current sports tourism resource development in Guangxi, this research summarizes the opportunities and countermeasures brought by sports tourism development, deeply explores the sports tourism resources in Guangxi, then puts forward valid and feasible development strategy, and provides references for the development of sports tourism routes.
\end{abstract}

Keywords-Guangxi; Sports tourism; Route development; SOWT analysis

\section{INTRODUCTION}

Along with the fast economic development in China, and the improvement of material standard of living, people's awareness of leisure tourism has been obviously reinforced. As the starting year for the "13th Five Year Plan", the Party and the government deeply interpreted and accurately positioned the word of "Healthy China" in 2016, and emphasized that public health must be realized in order to achieve all-round well-being, and it was also requested to place public health in the national strategic layer of preferential development; on October 25 of the same year, the Party Central Committee and the State Council officially released "Healthy China 2030" Plan Outline, thus, sports has become an important component for promoting public health and achieving all-round well-being[1]. As an important part of sports industry products, the development of sports tourism route is the core for carrying out modernized sports tourism economy development, and is the valid approach for realizing the development strategy of Healthy China.

In the recent years, along with the change of people's leisure concept, the pursuit for sports activities and health has become increasingly high, and sports tourism has become gradually popular. Guangxi has rich sports tourism resources, and the research emphasis of the paper is how to develop and utilize good sports tourism resources, convert them into product advantages, put forward reasonable suggestions, and fully utilize sports tourism resources, so as to promote the execution of Healthy China.

\section{DEVELOPMENT STATUS OF GUANGXI SPORTS TOURISM ROUTES}

Guangxi has rich natural tourism resources, and has generated lots of sports tourism projects, such as hiking, mountain-climbing, rock climbing, and drifting; besides, the proportion in the development of tourism projects in Guangxi is increasingly big, but as for the overall in route development of sports tourism, it is still in the initial period. In the current international society, sports tourism has become a popular tourism mode, and through holding Olympics, the Asian Games, World Youth Games and other kinds of large-scaled competitions; promoting various kinds of professional competitions, and developing leisure sports, the sports tourism industry of our country has also obtained unprecedented development. When being compared with the national sports tourism wave, the sports tourism in Guangxi still needs to be further developed and improved. Currently, the sports tourism in Guangxi is mostly emphasized on holding large-scaled competitions, and the sports tourism projects of partial scenic spots. Since 2015, there were above 450 competitions held and undertaken by Guangxi, of which there were about 60 international competitions, such as Guilin International Marathon Competition, Nanning International Half Marathon Competition, Liuzhou International Motorboat Competition as well as rock climbing, bike riding and other experience tourisms of individual regions. In 2017, it held the Bike Competition around Guangxi Highway, "China Cup" Soccer Game and other series of competition. Currently, sports competition tourists attracted to come here by its name failed to reach to the expected result, and lacked in competition holding place, the sports tourism resource development and sports tourism route plan of surrounding cities, and the time for tourists participating in sports tourism here is relatively short.

Author: Wang Dongle (1987- ), male, born in Baotou in Neimenggu Province, Master's of sports, lecturer, and research area: leisure sports tourism Communication Author: Liang Feng (1983- ), male, born in Zibo in Shandong Province, doctor of sports, lecturer, and research area: leisure sports tourism industry. 


\section{SOWT ANALYSIS OF GUANGXI SPORTS TOURISM ROUTE}

\section{A. The strengths of Guangxi Sports tourism route development}

1) Sports tourism resources, sports events and activities are abundant

Due to the rich tourism resources in Guangxi and the high attentions of the government for sports, since 2016, international sports competitions were frequently settled in Guangxi, and Guangxi became the world's sports event gathering place. Guangxi will energetically develop sports industry, perfect sports infrastructure, cultivate sports talents, revitalize Guangxi sports, and create a strong province of sports in the west of China." The emphasis of Guangxi Government on sports has increased sports competitions year by year, and through holding international competitions, more audiences and tourists come to Guangxi to participate in sports tourism and sightseeing.

\section{2) Superior geographical location and convenient} transportation

Guangxi is located at the coastal area and is close to ASEAN countries, and within the territory, it has several rivers, and is the interaction for the eastern region with the western and southeast parts; it is close to Pearl River Delta Economic Circle in the east, and is also close to the combined part of ASEAN economic circle, with advantageous geological position. Guangxi has two international airports, including Nanning and Guilin, and all cities have also opened the flight to all big and medium cities of the entire country. Besides, since July 1, 2017, as per the newest train operation drawing of Nanning Railway Bureau, the overall quantity of passenger train reached to 267.5 pairs, of which bullet train unit was increased to 211.5 pairs, occupying $79.1 \%$ of the total operating quantity of trains [2]. Especially the bullet train driving to four adjacent provinces, including Hunan, Guangdong, Guizhou and Yunnan was constantly encrypted, which had smoothed inter-provincial fast channel, and provided traffic convenience for tourists inside and outside the province.

3) The ecological environment is pleasant and suitable for sports tourism

Guangxi is located at the southwest national area of our country and is close to ASEAN countries, and has unique sports tourism resources. It has good geological position, pleasant climate, rich heat, sufficient rainfall, clear dry-wet division, moderate sunlight, more in summer and less in winter; from south to north, there are various natural sightseeing and tourist scenic sports and humanistic geological scenic spots. There are rich natural landscapes and humanistic resources that can be regarded as the destination of sports tourism, and currently, projects that have been put into use include drifting, rock climbing, pedestrianism, and bike.

\section{B. The weaknesses of Guangxi Sports tourism route development}

\section{1) Immature market development}

Rich sports tourism resources are unique resources, but the market immaturity has caused insufficient competition of Guangxi in attracting tourists. Firstly, it is expressed in insufficient publicity strength, and it is hard to find targeted sports tourism publicity advertisement in the tourism promotion in all places of Guangxi, and currently, it hasn't formed any brand promotion, and the market recognition degree of sports tourism market is insufficient. Secondly, the operation concept of management team remains to be reinforced, and the operation concept of managers is the key factor for market development. Through investigation, the current managers of various big scenic areas fail to attach enough attentions from sports tourism, and there are deficient professional management talents of sports tourism. Finally, due to the lack in market information, the market development should rely on correct market information, and the information source is the important guarantee for market development, and the lack in market confidence is also one of the important performances for the immature development of sports tourism market in Guangxi.

\section{2) Backward infrastructure}

The sports tourism scenic sports in Guangxi are often distributed at relatively remote villages and towns; although the infrastructure construction has been perfected over the years through holding large-scaled competitions "around Guangxi", "China Cup", etc., but these are merely restricted to the holding city and the routes along the route. Currently, the overall service infrastructure and circulated infrastructure construction in Guangxi are far behind those in developed regions along the sea. This has an extremely big influence on the tourism experience of tourists as well as the time for tourists to stay here. Besides, the medical treatment, sanitation, traffic infrastructure, and communication infrastructure in all places are unbalanced, scaring many domestic and overseas tourists off it.

\section{3) Fragile ecological environment}

Due to the low urban population capacity, and relatively weak infrastructure construction, with the increase in the quantity of tourists since this year, this has caused the phenomenon that various places have broken the original ecological balance with the increase of tourists, so as to absorb more tourists, and the ecological environment in partial regions is also seriously damaged, the water becomes mixed and the mountain becomes yellow. For instance, in Bama, Guangxi, through investigation, it has been found that the satisfaction degree of tourists for the ecological environment of Bama is obviously decreased, and the both the water and power supply are insufficient, and the flying dust and sewage treatment problems are also serious. 


\section{The opportunities of Guangxi Sports tourism route development}

1) Relevant policies support sports tourism

In May 2016, General Administration of Sport of China officially released the "13th Five Year Plan" for Sports Development; with respect to the adjustment of sports industry structure, the plan put forward the joint research about Sports Tourism Development Outline with the tourism department. After that, General Administration of Sport of China also released the Mountain Outdoor Activity Industry Development Plan, Aquatic Sports Industry Development Plan, and other policies supporting sports tourism development and a series of implementation documents considering the Notice about Promoting the Construction Work of Sports Leisure Characteristic Towns, and the Guidance Opinions about Energetically Developing Sports Tourism.

Along with the release of a series of relevant documents, sports tourism has been promoted to a new height. Meanwhile, such high-density policy support and financial support are the active signals consciously sent by the state considering the development of the leisure sports industry. Besides, the General Office of the State Council has also printed and issued the Guidance Opinions about Accelerating the Development of Fitness and Leisure Industry, and up till 2025, it will basically form the development pattern of fitness and leisure industry, and the overall scale has reached to RMB 3 trillion, of which the development of outdoor sports has become one of the important sports project leading the fitness and leisure industry. The successive release of national relevant policies is the important historical opportunities for the development of sports tourism in Guangxi.

\section{2) Local development promotes sports tourism}

With the high speed rails being successively opened, airports being gradually increased as well as highways and railways being successively opened, and various large-scaled sports competitions being settled at Guangxi, this has provided more opportunities for the publicity and promotion of sports tourism in Guangxi. With the holding of Bike Competition around Guangxi, Nanning "China Cup" International Football Championships, Resource International Drifting Competition and other kinds of competitions, it has made more sports tourism lovers of the whole country and even the entire world know about Guangxi and understand it, and then willingly come to Guangxi to participate in sports tourism experience. Besides, with the holding of various competitions, this has provided convenience for local residents to understand and participate in sports tourism activities, and as per the investigation and research about the Bike Competition around Guangxi, after observing the competition, $39.4 \%$ residents are willing to participate in bike sports or other sports activities afterwards.

\section{The threat of Guangxi Sports tourism route development}

\section{1) Insufficient attention is paid to sports tourism}

Currently, the development of sports tourism route hasn't attracted any attentions from various places yet, and the position in tourism route is relatively low. It fails to fully regard sports tourism route as the emphasis of a scenic spot or scenic area, and it is mainly emphasized on sightseeing tourism; according to the research data, only a few scenic sports or scenic areas provide some national characteristic sports project experience in the traveling process of tourists, without any special guidance service. This can show that the emphasis degree of scenic areas and the local for the sports tourism is insufficient, which has caused the lack in relevant input.

\section{2) Weak environmental awareness.}

Along with the increase in tourists, various places have increased construction and broken the original ecological balance, so as to absorb more tourists, and this has seriously damaged the ecological environment of partial areas, such as Bama of Guangxi; through investigation and research, it can be seen that, the satisfaction degree of tourists for the ecological environment of Bama has been obviously decreased, and problems such as infrastructure construction and environment damage are quite serious, which have directly influenced the tourist experience of tourists and their wishes to visit here again. All places of government have emphasized on environmental protection for several times, but in towns and villages, in order to develop tourism economy, the awareness for environment protection is generally very weak, and there are still problems about development first and governance later.

3) The nearby provinces and cities have carried out good sports tourism.

Currently, Beijing, Shanghai, Hainan and other provinces and cities have formed the sports tourism with initial scale, actively searched for cooperating with world famous brands, and after successfully operating China Open and other competitions, "La Liga" and NBA cooperation, the urban brand popularity and reputation have been largely improved, and the international competition has also been largely improved. Meanwhile, the aforementioned cities have attracted more and more global talents, funds, technologies and other liquid resources. Thus, in the face of the sports tourism market impact of other provinces and cities, our direct should establish characteristic brand, for instance, as the world famous competition, the influence of "the Bike Competition around Guangxi highway" is big, and by virtue of brand promotion, it has accelerated its steps for catching up with other provinces and cities. 


\section{COUNTERMEASURES FOR DEVELOPING GUANGXI SPORTS TOURISM ROUTES}

\section{A. Integrate resources and give full play to advantages}

Make an overall plan and collect the sports tourism resources of all places, divide them as per the characteristics of scenic spots, and design the sports tourism route with different difficulties and different contents. Combine leisure sightseeing travel with sports tourism, intensively create qualified routes, improve the infrastructure construction and environmental protection around the route, and then increase the tourism satisfaction degree of tourists and their time for staying here, and play the advantage resources of all places to the largest extent, and change the tourists' short sightseeing travel into in-depth leisure experience travel.

\section{B. Strengthen oversight and optimize services}

All levels of government should reinforce the supervision management of scenic spots. As for the price, service quality, catering sanitation and safety guarantee, etc., it is requested to strictly control, and reinforce the supervision, and strictly punish units or individuals with problems. The current network is highly developed; once price fraud, safety sanitation and other problems occur, for instance "Snow Country Event", "the Event about Lijiang Tourist Being Beaten" and other events can obviously decrease the previous publicity promotion effect.

\section{Cultivate the market and increase publicity}

Specific to the current public fitness wave, all places should seize opportunities, and plan for the sports tourism route, and specifically enhance publicity, and establish Guangxi brand. For instance, through relying on the Bike Competition around Guangxi highway, by virtue of the emphasis of the government, the competition level is high, it has created the bike tourism brand of Guangxi, and currently, there haven't been any other provinces creating bike tourism into the government-led sports tourism brand projects yet worldwide. It develops its own advantages, attracts tourists of the nearby developed provinces to Guangxi, and has also made more local residents participate in sports tourism, established the sports tourism market emphasized on local tourists and supplemented by foreign tourists.

\section{Sustainable environmental protection}

When discussing about environmental protection problems, General Manager Jinping Xi pointed out that "lucid waters and lush mountains are invaluable assets". The gorgeous environment is the unique natural condition for the sports tourism in Guangxi, and if we can well protect the environment, we can leave fortunes for our descendants. All places should combine the local development demands, formulate reasonable development plan and reinforce environmental protection, timely restrict excessive development or blind development, protect the local natural environment, and make sports tourism sustainable develop in local.

\section{CONCLUSION}

Under the perspective of Healthy China, the demand of national fitness and the desire of the people for a good life are important opportunities for the sports tourism development in Guangxi. Currently, the development of sports tourism route in Guangxi hasn't been mature yet, with lots of problems, and should attract more emphases and attentions. Through constantly conducting in-depth research, it has promoted the constant development and perfection of sports tourism route in Guangxi, and made the sports tourism in Guangxi more attractive.

\section{ACKNOWLEDGMENT}

This paper is one of the Guilin Tourism University Scientific research fund Project (2015QN11). Also is one of the phased achievements for the research subject: Research on Integrative Development of Guangxi leisure Sports Industry and Tourism Industry (17FTY004). And one of research results funded by Guangxi University's 100 Talents Program Research funding project.

Author: Wang Dongle (1987- ), male, born in Baotou in Neimenggu Province, Master's of sports, lecturer, and research area: leisure sports tourism.

Communication Author: Liang Feng (1983- ), male, born in Zibo in Shandong Province, doctor of sports, lecturer, and research area: leisure sports tourism industry.

\section{REFERENCES}

[1] Z. Y. Hu,J. H. Liang. Research on the Development of China's Sports Fitness and Leisure Industry from the Perspective of "Healthy China" [J]. Sports World (Scholarly), 2017 (09): 32-34.

[2] Y. Q. Li. Take More Attentions from Train Travel in July 1 [N]. Nanning Evening News 2017-06-11 (04).

[3] Jinping Xi. Place People's Health at the Strategic Position of Preferential Development and Strive to Realize All-dimensional and CompletePeriod Guarantee of People's Health [J]. Party Construction, 2016 (9): 4-5.

[4] Wenpeng Zhang. Expression about the Policy of School Sports Governance under the Perspective of Healthy China [J]. Journal of Beijing Sports University, 2018 (monthly) 94-100

[5] Jie Xu. Analysis on the Experience-type Sports Tourism Product Design and Route in Guilin [J]. Industrial Economy, 2008 (Feburary): 342-434.

[6] Zhipu Yang and Linling Zhang. SWOT Analysis and Countermeasures about the Ecological Civilization Construction of Weiyuan Island in Humen [J]. Ocean Development and Management, 2016 (7): 60-63.

[7] Yanyan Hou. SWOT Analysis of Tibetan Buddhism Cultural Tourism Resoruce Development in Chengde City [J]. Urban Tourism Planning, 2014 (9): 161-162.

[8] Hong Zou and Zhongping Xie. Research about the Development of Sports Tourism Cultural Resources of Our Country under the Background of Healthy China [J]. Contemporary Sports Technology, 2017, 7 (30): 158-159.

[9] F. Liang. Leisure Industry Management Model Considering Wilson Exponential Function[J]. Revista de la Facultad de Ingenieria U.C.V. 2017, vol 32, no 7, pp324-331 .

[10] F. Liang. Study on the Impact of Road Cycling on Event Tourism Development in Guilin of China[A]. International Conference on Management, Education and Social Sciencet(ICMESS 2018)[C].2018:06. 